\title{
Readiness to Use Village Funds to Support Community Independence (Case Study: Srirahayu Village, Cikancung District, Bandung Regency-Indonesia)
}

\author{
Aprilia Nur Aeni ${ }^{1 *}$, Asnita Frida Sebayang ${ }^{2}$, Aan Julia $^{3}$ \\ ${ }^{1,2,3)}$ Development Economics Department, Faculty of Economics and Business, Bandung Islamic University \\ Corresponding Author Email: aprilnura27@gmail.com
}

\section{Received: 13/09/2019}

Accepted: 27/09/2020

Keywords: Village Fund, Srirahayu Village, Readiness Stage, Quantitative SWOT

\begin{abstract}
Village funds are funds sourced from the APBN with the hope of increasing community independence. However, in its management, there are still problems, namely the unpreparedness of the community and village officials. Srirahayu Village is the village with the lowest IDM. In its management, village funds are mostly used for physical development. The research objective was to determine, measure, study, and formulate strategies for handling the level of readiness to use village funds to support community independence in Srirahayu Village. The method used is descriptive analysis with a quantitative approach. Data was collected through questionnaires to 5 respondents (village officials). Techniques for measuring community readiness consist of No Awareness, Denial / Resistance, Vague awareness, Preplanning, Preparation, Initiation, Stabilization, Expansion / Confirmation, Community Ownership. The results showed the level of readiness to use village funds to support community independence in Srirahayu Village by using 5 readiness dimensions, namely general knowledge about village funds at a score of 5.2 (preparation), leadership at 6.2 (initiation), community climate on the score. 5.8 (preparation), knowledge of the use of village funds for community independence at a score of 5.8 (preparation), and resources at a score of 5.0 (preparation), so that the average readiness to use village funds for community independence in Srirahayu Village is a score of 5.6 or being in the preparation stage.
\end{abstract}

\section{INTRODUCTION}

One of the problems that have always been a concern in Indonesia is equitable development by its portion, the current government is very concerned about village development. The village law has also been stated in Law No.6 of 2014 as a form of readiness of the government in the real context that the village is a legal community unit that has the authority to regulate and manage government affairs, the interests of the local community based on community initiative, rights of the origin or traditional rights recognized and respected in the government system of the Republic of Indonesia (Village, 2013). The government in the era of President Joko Widodo began by prioritizing villages in the Nawa Cita program. One of the programs of Nawa Cita is to develop Indonesia from the periphery by strengthening several regions and villages within the framework of a unitary state. Prasetyo (in Miftahudin, 2018) argues that the program was planned because the villages were not given much attention by the government in the previous era so that infrastructure development was not evenly distributed. For this reason, it is hoped that development in rural areas will increase, easier access, be economically independent, and able to manage each village. The Village Fund is a source of financial funds originating from the State budget (in Indonesia is called APBN) which is budgeted annually and given to each village as a source of village income. With the Village Fund, the source of income in each village will increase. The increase in village income provided by the government is to increase the standard of living of the village community. But with the existence of the Village Fund also raises new problems in management, the village government is expected to be able to manage by statutory regulations efficiently, economically, effectively and transparently and responsibly by paying attention to a sense of justice and compliance and prioritizing the interests of the community (Ferina et al., 2016 ). West Java Province is one of the largest recipients of village funds in Indonesia. This province receives village funds of 5.7 trillion with the number of villages as many as 5,312 villages. The rural poverty rate in West Java Province in 2019 was 9.79\%. Bandung Regency has a 2019 Building Village Index of 0.7229 or is in the first position of other districts. With this, it means that village development in Bandung Regency is high compared to others. Based on data from the Ministry of Health, PDTT 2019, Bandung Regency, there are 136 developing villages, 104 developed villages, and 26 independent villages. In 2019, Bandung district itself 
received village funds of IDR 311 billion, with a total of 270 villages. Cikancung Subdistrict is a part of Bandung Regency, this sub-district has a low Build Village Index of 0.6787. Compared to the others, Srirahayu Village has the lowest IDM, which is 0.6100 and is ranked 9th out of 9 villages in Cikancung District and is a developing village, which means that the village has the potential to become a developed village, which has social, economic and ecological resources but have not managed it optimally to improve the welfare of rural communities, the quality of human life and alleviate poverty. For this reason, through village funds, the village government can improve the standard of living and welfare through the establishment of policies, programs, and activities that are by the needs of the community. Srirahayu Village in 2019 received village funds of Rp. 1,679,132,000 for APBDesa revenue from village funds, regional tax and retribution revenue sharing, village fund allocation, district financial assistance, provincial financial assistance, and the village's income was managed to get Rp. 3,057,157,200 and their use was allocated for development by 67.2\%, government administration at $15.4 \%$, community empowerment by $15 \%$, and in the field of community development by $2.2 \%$. From these data, it can be seen that there is still a lack of community empowerment and coaching that can foster community independence if you look at the village has various sectors such as agriculture, plantation, and also tourism that can be encouraged to become a livelihood for the village community. So, there is no need for villagers to move to cities just to improve their welfare. One thing that can improve the welfare of the community and village is the use of Village-owned enterprises (in Indonesia is called BUMDes) with the benefits that will be obtained is an increase in income. Apart from the village, the benefits of BUMDes can also be felt by the village community to create products, raise the potential of the village, create jobs, and become more productive which of course will affect increasing the community's economy. In research conducted by Kurniasih (2017), the management of BUMDes in the Banyumas Regency has not been running optimally. The findings of several BUMDes indicate that BUMDes management is still managed simply. The manager's role is still very weak. As a result, the benefits of BUMDes cannot be felt by the village community. Based on the results of observations, It appears that the majority of BUMDes management still tends to involve elements of the village government, especially the village head in a central position in decision making. As a result, managers do not have creativity in running BUMDes. To achieve increased welfare for both the village and the community, it is necessary to prepare the government for the use of village funds. Given that the role of the village head and its apparatus in allocating village funds is very important, so that community needs can be met. Based on problem identification, the objectives to be achieved in this study are to (1) find out, measuring and assessing the readiness of using village funds to support the independence of the case study community in Srirahayu Village, Cikancung District, Bandung Regency (2) knowing strategies to increase the readiness to use village funds to support community independence for case studies of Srirahayu Village, Cikancung District, Bandung RegencyIndonesia.

\section{LITERATURE REVIEW}

Supriatna (2000) states that development in a village is a development that is carried out comprehensively with harmonious obligations between the government and the community, where the government is obliged to provide assistance, facilities, guidance, and direction. Meanwhile, the community participates in the form of self-employment and self-help community cooperation in any development desired to increase the income and welfare of rural communities. Adisasmita (2006) explains that rural development is directed at managing and utilizing owned development resources (HR and SDA). Second, to improve inter-sectoral development linkages (trade, agriculture, and industry) between villages, between rural and urban areas, and third, for overall national development. Soleh (2014) explains that rural economic activities are part of national economic activities which involve the linkage of activities between urban and rural areas (urban-rural economic linkages). The process of transforming rural communities or the development of rural communities has a goal of creating an advanced and productive village community. Based on Law Number 6 of 2014 and Government Regulation Number 60 of 2014 that the use of village funds is prioritized for the development and empowerment of village communities following the priority of using village funds set by the Ministry of Village, PDT, and Transmigration The process of transforming rural communities or the development of rural communities has a goal of creating an advanced and productive village community. Based on Law Number 6 of 2014 and Government Regulation Number 60 of 2014 that the use of village funds is prioritized for the development and empowerment of village communities by the priority of using village funds set by the Ministry of Village, PDT and Transmigration The process of transforming rural communities or the development of rural communities has a goal of creating an advanced and productive village community. Based on Law Number 6 of 2014 and Government Regulation Number 60 of 2014 that the use of village funds is prioritized for the development and empowerment of village communities by the priority of using village funds set by the Ministry of Village, PDT, and Transmigration(Village, 2013). Each stage of the village financial management process has rules that must be understood and implemented according to predetermined time limits. Arif (2007) states that village financial management is an activity that includes planning, budgeting, accountability reporting, and monitoring of village finances. Teguh (2004) argues that community independence is a condition experienced by society and is characterized by the ability to think, decide and do something that is deemed appropriate to achieve solving the problems at hand, to achieve independence it is necessary to support the ability in the form of human resources intact with cognitive, conative, psychomotor and affective conditions, and other physical-material resources. The development of village independence can be realized through the management and allocation of village funds through implementing a series of strategies through restructuring village institutions, strengthening village economic institutions, and empowering communities. In four aspects (cognitive, conative, affective, 
and psychomotor) it will contribute to the creation of the independence of the community that you aspire to.(Teguh, 2004). Through the learning process, the community will gradually acquire the ability/power from time to time, thereby increasing their ability to deliver their independence, which is expected from empowerment which is a visualization of development that is expected to create a good community and an ideal society. The concept of community readiness was developed by the Tri-Ethnic Center for Prevention Research (2014) and makes a community readiness model which is divided into 9 (nine) stages: 1) No awareness. At this stage the community or community group is not aware of the current issue and does not yet know any problems that need to be resolved; 2) Denial. At this stage, some people are aware of the issue but the condition that develops is that people are apathetic; 3) Vague Awareness. At this stage some of the community is aware of the developing issues and the need to do something to overcome these issues; 4) Preplanning. At this stage there is already an understanding of the problem that must be solved together; 5) Preparation. At this stage, there is general information that has developed in the community regarding the problems at hand, the pros and cons in the established community and actions and policies taken; 6) Initiation. At this stage, the community has started to be active and there is no resistance; 7) Stabilization. At this stage the programs, activities, and policies are standardized. A trained and experienced community has been formed. There is still little perception to change or expand treatment efforts. There is no program evaluation of program effectiveness; 8) Confirmation / Expansion. At this stage there is already a standard regarding the business (activities and policies), there is already an authority or community that supports the expansion and improvement of the business; 9) High level of community ownership. At this stage, there is already more detailed and up-to-date information about the causes and consequences. Evaluation that is effective in improving and developing programs that are already running well. According to Rangkuti (2005), SWOT analysis is the systematic identification of various factors to formulate a company strategy. This analysis is based on a logic that maximizes strength (strength) and opportunities (opportunity). but simultaneously it can minimize weakness (weakness) and threats (threats). The SWOT analysis method is considered the most basic method of analysis, which is useful for looking at a topic or problem from four different sides. The result of the analysis is to increase the benefits of existing opportunities, by reducing shortages and avoiding threats. To analyze more deeply about SWOT, it is necessary to look at external and internal factors as an important part of a SWOT analysis. These external factors affect the formation of opportunity and threats $(\mathrm{O}$ and $\mathrm{T})$. Where these factors are related to conditions that occur outside the company that affects the company's decision making. Meanwhile, internal factors will influence the formation of strength and weakness ( $\mathrm{S}$ and $\mathrm{W}$ ) where this factor relates to the conditions that occur in the company, which also affects the formation of company decision making. The SWOT matrix as a matching tool develops four types of SO, WO, ST, and WT.

\section{METHODOLOGY}

The research method used in this research is to use descriptive analysis method with a quantitative approach. Sugiyono, (2018) explained that the descriptive method of analysis is a method that serves to describe or give an overview of the object under study through data or samples that have been collected as is without analyzing and making general conclusions. Meanwhile, the quantitative approach is the approach used in research by measuring the indicators of the research variables to obtain an overview of these variables. The data used in this study are primary data and secondary data. Primary data was obtained through the interview process by distributing questionnaires directly and the method used was The Community Readiness Model (CRM) using key respondents to answer questions. The key respondents in this study are people who understand how to manage village funds as policymakers. Respondents consisted of resource persons from village officials, namely the village head, village secretary, head of the government section, head of the service section, head of the welfare section, and also BUMDes. Secondary data are obtained by people who research existing sources (Hasan, 2002). This study uses secondary data obtained from the website of the Central Statistics Agency (BPS) West Java, BPS Bandung Regency, Cikancung District in numbers, Srirahayu Village profiles, Srirahayu Village documents, and mass media. In analyzing the data, the method used is The Community Readiness Model. This model was originally developed by the Tri-Ethnic Center at the College of Natural Sciences in the 1995 Department of Psychology at Colorado State University. The community readiness model is used to assess the level of community awareness, involvement, attitudes, and behavior towards issues, and the community climate for change. There are five dimensions of society as follows: 1) community knowledge regarding village funds; 2) leadership; 3) community climate; 4) efforts to make community knowledge about the use of village funds for independence; 5) resources, namely the extent to which local resources (human resources, time, money, and space) to support village funds for community independence. After conducting the interview, the next step is to determine the assessment of each key respondent who was interviewed by referring to The community readiness model is used to assess the level of community awareness, involvement, attitudes, and behavior towards issues, and the community climate for change. There are five dimensions of society as follows: 1) community knowledge regarding village funds; 2) leadership; 3) community climate; 4) efforts to make community knowledge about the use of village funds for independence; 5) resources, namely the extent to which local resources (human resources, time, money, and space) to support village funds for community independence. After conducting the interview, the next step is to determine the assessment of each key respondent who was interviewed by referring to The community readiness model is used to assess the level of community awareness, involvement, attitudes, and behavior towards issues, and the community climate for change. There are five dimensions of society as follows: 1) community knowledge regarding village funds; 2) leadership; 3) community climate; 4) efforts to make community knowledge about the use of village funds for independence; 5) 
resources, namely the extent to which local resources (human resources, time, money, and space) to support village funds for community independence. After conducting the interview, the next step is to determine the assessment of each key respondent who was interviewed by referring to There are five dimensions of society as follows: 1) community knowledge regarding village funds; 2) leadership; 3) community climate; 4) efforts to make community knowledge about the use of village funds for independence; 5) resources, namely the extent to which local resources (human resources, time, money, and space) to support village funds for community independence. After conducting the interview, the next step is to determine the assessment of each key respondent who was interviewed by referring to There are five dimensions of society as follows: 1) community knowledge regarding village funds; 2) leadership; 3) community climate; 4) efforts to make community knowledge about the use of village funds for independence; 5) resources, namely the extent to which local resources (human resources, time, money, and space) to support village funds for community independence. After conducting the interview, the next step is to determine the assessment of each key respondent who was interviewed by referring to(Tri-Ethnic Center for Prevention Research, 2014) with nine measures of readiness stages, namely No Awareness, Denial / Resistance, Vague Awareness, Preplanning, Preparation, Initiation, Stabilization, Expansion / Confirmation, Community ownership.

\section{RESULT AND DISCUSSION}

By the identification of problems and objectives in research, Then in this discussion, a discussion of the readiness of rural communities will be presented from the perspective of the village head, village secretary, head of government, a section of welfare, service, and BUMDes administrators in the use of village funds for community independence and strategies for handling readiness levels using a case study SWOT analysis. in Srirahayu Village, Cikancung District, Bandung Regency. In the process of knowing community readiness, there are five dimensions of readiness, namely general public knowledge, leadership, community climate, knowledge efforts about the use of village funds for community independence and resources. To determine the readiness of the community in the use of village funds to support community independence, it is assisted by the Community Readiness Model method.

\subsection{Level of Community Readiness}

In determining the score, per dimension is obtained from the calculation of the average of all scores with the number of dimensions. The average is obtained by dividing the total score by the number of dimensions, so the readiness stages can be obtained consisting of No Awareness, Denial / Resistance, Vague Awareness, Preplanning, Preparation, Initiation, Stabilization, Expansion / Confirmation, Community ownership. After the readiness stage is known, the next is determining the strategy in each level of readiness, using a quantitative SWOT analysis. To obtain a score about the readiness of the community in using village funds to support community independence in Srirahayu Village, Cikancung District, Bandung Regency, data processing was carried out through structured interviews with respondents. The results of data processing, obtained by the readiness stage of Srirahayu Village in the following Table 1.

Table 1. Readiness stage by dimension in Srirahayu Village

\begin{tabular}{lcc}
\hline \multicolumn{1}{c}{ Dimensions } & Score & Readiness Stage \\
\hline General knowledge about village funds & 5.2 & Preparation \\
Leadership & 6.2 & Initiation \\
Community Climate & 5.8 & Preparation \\
Community knowledge about issues (Use of village funds to & 5.8 & Preparation \\
support community independence) & & \\
Resource & 5.0 & Preparation \\
\hline Total & $\mathbf{2 8}$ & Preparation \\
\hline Average & $\mathbf{5 , 6}$ &
\end{tabular}

Table 1 indicates that the one with the lowest score is the fifth dimension, namely the resource dimension. The highest score is the second dimension, namely leadership. The results of this study indicate that the readiness stage of Srirahayu Village, Cikancung District, Bandung Regency is at a score of 5.6, namely (preparation). At this stage, there is general information that develops in the community, the pros and cons of the community in the community, and a policy that has been taken. Based on the explanation of each stage of community readiness, the preparation stage has the following meanings: 1) Almost all the people of Srirahayu Village, Cikancung District have heard of the use of village funds for community independence. 2) Community leaders (village officials, village consultative bodies, and village non-government organizations) actively support the continuation and increase in the use of village funds as well as the attitude of the community to care and want to do something about the use of village funds to support community independence. 3) several resources can be used for further efforts in using village funds to support community independence and active community leaders to work to secure these resources. The ideal level of community readiness is with a score of 9 (nine), at this stage the community. To determine the ratio of the ideal number is the ideal number reduced by the number in the readiness stage 
contained in each dimension of readiness. The comparison of the distance to the ideal number of scores per readiness dimension in Srirahayu Village, Cikancung District can be seen in Figure 1.

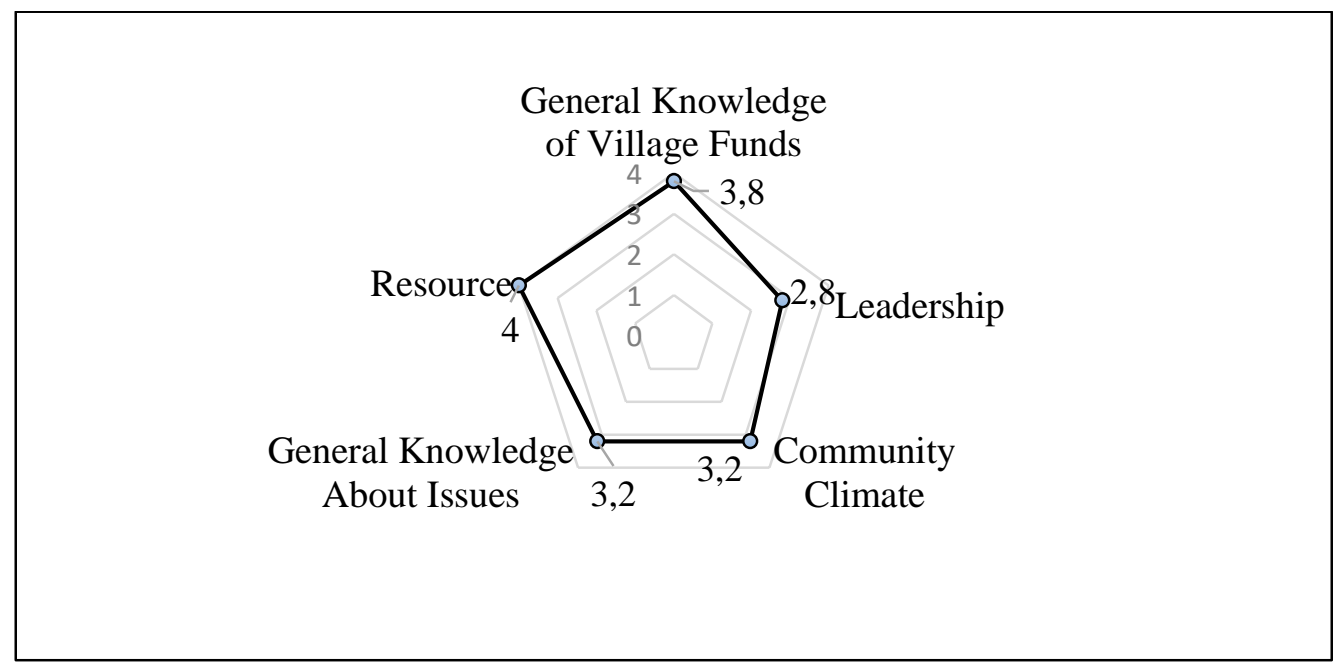

Source: Researcher Process, 2020.

Figure 1. Distance between Dimensions of Readiness to Ideal Numbers

Figure 1.shows that the higher the readiness dimension score is, the closer it is to the ideal number and vice versa. The dimension of readiness in Srirahayu Village that is the farthest away from the ideal figure is the dimension of general knowledge of village funds and resources. The distance between the general knowledge of village funds and the ideal number is 3.8 and the distance between resources and the ideal number is 4.0. This long-distance requires priority handling compared to other dimensions. Meanwhile, the dimension with the closest distance is leadership.

\subsection{Analysis of the Level of Readiness of Srirahayu Village, Cikancung District}

\subsubsection{General Knowledge Dimensions}

The results showed that the general knowledge dimension had a score of 5.2 or was in the preparation stage. At the level of awareness, it shows that at least some people in Srirahayu Village have heard of programs made using village funds and know about the objectives of the program. The attitude of the community towards the problem with the direction given by the village government is that they care and have a desire to do something, one of which is by regularly following the briefings that are held. In the results of calculations that have been assessed the level of knowledge shows the benefits of village funds have the highest score.

\subsubsection{Leadership Dimensions}

The leadership dimension in this study is at the highest score, namely 6.2 at the initiation stage. At this stage, there are at least several community leaders (leaders) who play a key role, participate in developing, improving, and implementing the use of village funds. Some communities have at least some knowledge of the planning of the Village Head regarding activities or programs that will be carried out through meetings or meetings held. The efforts that have been made so far by the Village Head are to become role models for the community and work sincerely, fairly, and without strings attached. This can foster community trust in Srirahayu Village which encourages community volunteering to carry out cooperation in physical development carried out by the village.

\subsubsection{The Climate Dimensions of Society}

This dimension has a score of 5.8 or is in the preparation stage. At this stage the community gives a positive attitude, this is indicated by spending time participating in meeting activities, supporting various knowledge or opinions. The results of the questionnaire show that community support following village meetings has the highest score, community involvement can of course unite different opinions in solving a problem of mutual interest. In the implementation of the Musrenbang meeting, several communities provided support by attending and participating in providing suggestions and opinions regarding what programs would be carried out in building the village in the future.

\subsubsection{Dimensions of General Knowledge about Issues (Use of Village Funds to Support Community Independence)}

This dimension has a score of 5.8 or is in the preparation stage. At this stage there are at least some people who know about the use of village funds, why it is necessary to use village funds for independence, the consequences, and the program is implemented in the surrounding area. Development of village funds for independence, the community has a basic knowledge of programs/activities, they know the causes, consequences, signs, and symptoms. In the SME empowerment program (creative economy industry making simplicity), the community is involved in the context of program decision making. The community made several proposals for empowerment programs. The community also actively participates in these activities. Apart from conducting UKM training, 


\subsubsection{Resource Dimensions}

This dimension has a score of 5.0 or is in the preparation stage. At this stage, several resources can be used regarding the issue of village funds. Several community members and leaders are actively working to develop resources. The human resources in Srirahayu Village still need to be explored, various skilled workers in the fields of agriculture, plantations, animal husbandry, agricultural machinery industry, workshops, and technology and information as well as others. In the resource of time, the community voluntarily participates in various meetings and activities. One of the efforts made by village officials to optimize the use of village funds is by developing BUMDes. BUMDes in Srirahayu Village is designed as one of the Perusdes Panggung Lestari business units which are engaged in environmental management services.

\subsection{Strategies for Handling the Level of Readiness}

\subsubsection{SWOT analysis}

In this study, a strategy was selected and formulated based on the score obtained from the multiplication of the weight and rating obtained from the key informants. The SWOT matrix in this analysis is divided into two, namely:

A. IFAS Analysis (Internal Strategic Factors Summary)

In the analysis of IFAS (Internal Strategic Factors Summary), namely internal factors consisting of strengths and weaknesses, the calculation results of Weight (B) X Rating (R) are obtained and there are the following results:

\section{Table 2. Internal Factors (Strength and Weakness)}

\begin{tabular}{|c|c|c|c|}
\hline \multicolumn{3}{|r|}{ Internal factors } & Weight $\quad$ Rating (R) $\quad$ Score $(B \times R)$ \\
\hline
\end{tabular}

(B)

\begin{tabular}{|c|c|c|c|c|}
\hline \multicolumn{5}{|c|}{ A. Strength } \\
\hline & Availability of natural resources that can still be extracted & 0.10 & 3.6 & 0.37 \\
\hline 2. & Has advantages in the field of cattle farming & 0.12 & 4 & 0.48 \\
\hline 3. & Has many people who are in their productive age & 0.10 & 3.8 & 0.37 \\
\hline & There is a facilitator or village assistant in managing village funds & 0.10 & 3.6 & 0.35 \\
\hline & The existence of BUMDes in supporting community independence & 0.11 & 3.6 & 0.38 \\
\hline & Skilled local workforce & 0.07 & 3.4 & 0.25 \\
\hline \multicolumn{2}{|c|}{ Total Value } & 0.59 & & 2.19 \\
\hline \multicolumn{5}{|c|}{ B. Weaknesses } \\
\hline & $\begin{array}{l}\text { The number of young people lacking desire in the field of } \\
\text { entrepreneurship }\end{array}$ & 0.06 & 2 & 0.13 \\
\hline 2. & $\begin{array}{l}\text { Many productive businesses have traditional patterns. Both related to } \\
\text { production patterns, technology, business partnership, and marketing } \\
\text { patterns. }\end{array}$ & 0.07 & 1.8 & 0.13 \\
\hline & $\begin{array}{l}\text { The quality of human resources (school participation rate) is still } \\
\text { relatively low }\end{array}$ & 0.09 & 1.4 & 0.12 \\
\hline 4. & There is still a lack of funding in the empowerment and guidance sector & 0.08 & 1.6 & 0.13 \\
\hline & Village government that is less innovative in building villages & 0.05 & 2 & 0.10 \\
\hline & Cooperation between existing institutions is not optimal & 0.05 & 2 & 0.11 \\
\hline \multicolumn{2}{|r|}{ Total Value } & 0.41 & & 0.71 \\
\hline \multicolumn{2}{|c|}{ Total } & 1 & & 2.90 \\
\hline
\end{tabular}

Source: Researcher Process. 2020.

Based on the value obtained. Internal factors The main strength of using village funds to support community independence is having an advantage in the field of cattle farming, namely 0.48 . The main weakness in using village funds to support community independence is that many young people lack desire in the field of entrepreneurship. many productive businesses have traditional patterns. Both related to production patterns. technology. business partnership. and marketing patterns. And there is still a lack of funding in the field of empowerment and guidance, which are both worth 0.13.

B. EFAS (External Strategic Factors Summary) Analysis

In the EFAS (External Strategic Factors Summary) analysis, namely external factors consisting of opportunities and threats, the weight (B) X Rating (R) calculation results are obtained and there are the following results: 
Table 3. External Factors (Opportunity and Threats)

\begin{tabular}{lllll}
\hline No. & External Factors & Weight & Rating (R) & Score (BxR)
\end{tabular}

(B)

1. Information Development. Science and technology

$\begin{array}{lll}0.13 & 3.6 & 0.47\end{array}$

2. There is support from the local government in BUMDes capital

0.13

3.8

0.50 participation

3. Policy regarding the transfer of village fund allocations

$\begin{array}{lll}0.10 & 3.2 & 0.31\end{array}$

4. There is training from the central government to encourage people to

0.06

4

0.23 improve their skills

5. The pattern of consumption/purchasing power of the people increases

\section{Total Value}

0.11

\section{B. Threats}

1. Uncertain economic conditions due to the Covid-19 pandemic

$\mathbf{0 . 5 3}$

3.2

0.36

2. Tight business competition, especially from large entrepreneurs, can

0.14

0.13

1.8

1.87 threaten the existence of SMEs.

3. Natural resource management in other locations is better / modern / more advanced

4. The openness of public knowledge so that superior products are not

0.10

0.25 unique

\begin{tabular}{lcc}
\hline Total Value & 0.47 & 0.74 \\
\hline Total & 1 & 2.61 \\
\hline
\end{tabular}

Source: Researcher Process. 2020.

Based on the value obtained. External factors that have an opportunity to use village funds to support community independence are the support from the government in BUMDes capital participation with a score of 0.50. Meanwhile, the main threat faced is uncertain economic conditions due to the Covid-19 pandemic which is currently happening with a score of 0.25 .

Table 4. Results of the SWOT Matrix Analysis of the Use of Village Funds to Support Community Independence in Srirahayu Village

\begin{tabular}{|c|c|c|}
\hline Internal factors & Strength (S) & Weakness (W) \\
\hline External Factors & $\begin{array}{l}\text { 1. Availability of natural resources that } \\
\text { can still be extracted } \\
\text { 2. Has advantages in the field of cattle } \\
\text { farming } \\
\text { 3. Having many people who are in their } \\
\text { productive age } \\
\text { 4. There is a facilitator or village } \\
\text { assistant in managing village funds } \\
\text { 5. The existence of BUMDes in } \\
\text { supporting community independence } \\
\text { 6. Local workers who have expertise }\end{array}$ & $\begin{array}{l}\text { 1. The number of young people lacking } \\
\text { desire in the field of entrepreneurship } \\
\text { 2. Many productive businesses have } \\
\text { traditional patterns. Both related to } \\
\text { production patterns. technology. business } \\
\text { partnership. and marketing patterns. } \\
\text { 3. The quality of human resources (school } \\
\text { participation rate) is still relatively low } \\
\text { 4. There is still a lack of funding in the field } \\
\text { of empowerment and guidance } \\
\text { 5. Village governments that are less } \\
\text { innovative in developing villages } \\
\text { 6. Cooperation between existing institutions } \\
\text { is not optimal }\end{array}$ \\
\hline Opportunity (O) & SO strategy & WO strategy \\
\hline $\begin{array}{l}\text { 1. Information } \\
\text { development. Science and } \\
\text { technology } \\
\text { 2. There is support from } \\
\text { local governments in } \\
\text { BUMDes capital } \\
\text { participation } \\
\text { 3. Policy regarding the } \\
\text { transfer of village fund } \\
\text { allocations } \\
\text { 4. There is training from } \\
\text { the central government to }\end{array}$ & $\begin{array}{l}\text { 1. Optimizing capital support from the } \\
\text { local government for BUMDes in } \\
\text { supporting the economic independence } \\
\text { of the community. } \\
\text { 2. Improve human resource capacity } \\
\text { training through the use of technology to } \\
\text { manage Natural Resources more } \\
\text { productively. } \\
\text { 3. Increasing skills in managing local } \\
\text { resources including the development of } \\
\text { up-skilling cattle farms and other } \\
\text { superior products. }\end{array}$ & $\begin{array}{l}\text { 1. Increase cooperation between labor } \\
\text { agencies in encouraging people to improve } \\
\text { their skills. } \\
\text { 2. Increase funding for guidance and } \\
\text { empowerment with BUMDes capital to } \\
\text { increase community income. }\end{array}$ \\
\hline
\end{tabular}




\begin{tabular}{|c|c|c|}
\hline Internal factors & Strength (S) & Weakness (W) \\
\hline External Factors & $\begin{array}{l}\text { 1. Availability of natural resources that } \\
\text { can still be extracted } \\
\text { 2. Has advantages in the field of cattle } \\
\text { farming } \\
\text { 3. Having many people who are in their } \\
\text { productive age } \\
\text { 4. There is a facilitator or village } \\
\text { assistant in managing village funds } \\
\text { 5. The existence of BUMDes in } \\
\text { supporting community independence } \\
\text { 6. Local workers who have expertise }\end{array}$ & $\begin{array}{l}\text { 1. The number of young people lacking } \\
\text { desire in the field of entrepreneurship } \\
\text { 2. Many productive businesses have } \\
\text { traditional patterns. Both related to } \\
\text { production patterns. technology. business } \\
\text { partnership. and marketing patterns. } \\
\text { 3. The quality of human resources (school } \\
\text { participation rate) is still relatively low } \\
\text { 4. There is still a lack of funding in the field } \\
\text { of empowerment and guidance } \\
\text { 5. Village governments that are less } \\
\text { innovative in developing villages } \\
\text { 6. Cooperation between existing institutions } \\
\text { is not optimal }\end{array}$ \\
\hline \multicolumn{3}{|l|}{$\begin{array}{l}\text { encourage people to } \\
\text { improve their skills } \\
\text { 5. The pattern of } \\
\text { consumption/purchasing } \\
\text { power increases }\end{array}$} \\
\hline Threat $(\mathrm{T})$ & ST strategy & WT strategy \\
\hline $\begin{array}{l}\text { 1. Uncertain economic } \\
\text { conditions due to a } \\
\text { pandemic } \\
\text { 2. Tight business } \\
\text { competition, especially } \\
\text { from large entrepreneurs, } \\
\text { which can threaten the } \\
\text { existence of SMEs. } \\
\text { 3. Natural resource } \\
\text { management in other } \\
\text { locations is better / modern } \\
\text { / more advanced tools } \\
\text { 4. Openness of public } \\
\text { knowledge so that superior } \\
\text { products are not unique }\end{array}$ & $\begin{array}{l}\text { 1. Increasing the competitiveness of } \\
\text { products and the role of SMEs in the } \\
\text { regional / village economy. } \\
\text { 2. Improve the quality of Natural } \\
\text { Resources (SDA) in the utilization of } \\
\text { science and technology. }\end{array}$ & $\begin{array}{l}\text { 1. Increase the role of village facilitators by } \\
\text { local needs, including understanding the } \\
\text { rules for managing village funds. } \\
\text { 2. Identifying products that have } \\
\text { attractiveness and high economic value and } \\
\text { make these products become superior } \\
\text { products that are characteristic of Srirahayu } \\
\text { Village. }\end{array}$ \\
\hline
\end{tabular}

Source: Researcher Process. 2020.

Based on the results of the analysis with the SWOT matrix, it is found that the SO (Strength-Opportunity) strategy is the most optimal strategy to increase the use of village funds to support community independence in Srirahayu Village. From the formulation of the main strength $(\mathrm{S})$ and opportunity $(\mathrm{O})$ factors. there are three strategies obtained. that is :

[1] Optimizing the support capital of the local government for BUMDes in supporting the economic independence of the community.

[2] Improve human resources through training in the use of technology so that they can manage natural resources more productively.

[3] Increased skills in managing local resources including the development of up-skilling cattle farms and other superior products.

\section{CONCLUSIONS}

The readiness stage is based on the concept of the Tri-Ethnic Prevention Center (2014) that Srirahayu Village, Cikancung District, Bandung Regency, at a score of 5.6, namely (preparation). The preparation stage means: Almost all people of Srirahayu Village, Cikancung District have heard about the use of village funds for community independence in the form of UKM empowerment programs and guidance such as sewing and motorbike service. Community leaders (village officials, village consultative bodies, and village non-governmental organizations) actively support the continuation and increase in the use of village funds and the attitude of the community to care and want to do something about the use of village funds to support community independence. Several resources can be used for further efforts to use village funds to support community independence and active community leaders to work to secure these resources. While the strongest dimension in this study is the leadership dimension at a score of 6.2 or the initiation stage. Meanwhile, the weakest dimension in this study is the resource dimension at a score of 5.0 or the preparation stage. Based on the results of the 
SWOT analysis of internal factors, namely the strengths that are owned are greater than the weaknesses and the difference is 1.48. Meanwhile. based on the calculation of the difference between the external factors, the opportunity is greater than the threat and the difference is 1.13. The results show that the SO (Strength-Opportunity) strategy is the most optimal strategy to increase the use of village funds to support community independence in Srirahayu Village.

\section{ACKNOWLEDGMENT}

The author would like to express his gratitude to both parents. family. and friends who have given their encouragement and support. The author also wishes to express his deepest gratitude to all Development Economics lecturers who have provided knowledge and do not forget to thank the alma mater of the Islamic University of Bandung, which is the place for writers to seek knowledge. The author also thanks to all respondents from this research for all their assistance. time and willingness to help the author so that the author can complete this research.

\section{REFERENCES}

Adisasmita. (2006). Pembangunan Pedesaan dan Perkotaan. Yogyakarta: Graha Ilmu.

Desa. U. (2013). Undang-Undang Republik Indonesia Nomor 6 Tahun 2014 Tentang Desa. Journal of Chemical Information and Modeling.

Ferina. B. H. (2016). Tinjauan Kesiapan Pemerintah Desa Dalam Implementasi Peraturan Menteri Dalam Negeri Nomor 113 Tahun 2014 Tentang Pengelolaan Keuangan Desa (Studi Kasus Pada Pemerintah Desa di Kabupaten Ogan Ilir). Jurnal Manajemen dan Bisnis. 14 (3): $321-326$.

Hasan. I. (2002). Pokok-Pokok Materi Metodologi Penelitian dan Aplikasinya. Jakarta: Ghalia Indonesia.

Kurniasih. D. (2017). Kegagalan Bisnis Pemerintah Desa (Studi tentang Relasi Bisnis-Pemerintah pada Pengelolaan Badan Usaha Milik Desa di Kabupaten Banyumas). Journal of Public Sector Innovations. 66-72.

Miftahuddin. (2018). Akuntabilitas dan Transparansi Pemerintah Desa Terhadap Pengelolaan Dana Desa (Studi Kasus : Desa Panggungharjo Kecamatan Sewon Kabupaten).

Rangkuti. F. (2005). Analisis SWOT Teknik Membedah Kasus Bisnis. Jakarta: PT. Gramedia Pustaka Utama.

Research. T. E. (2014). Community Readiness for Community Changes. Colorado US.

Soleh. C. (2014). Dialetika Pembangunan dan Pemberdayaan. Bandung: Fokus Media.

Sugiyono. (2018). Metode Penelitian Kuantitatif. Kualitatif dan R\&D. Bandung: Alfabeta.

Supriatna. T. (2000). Strategi Pembangunan dan Kemiskinan. Jakarta: Rineke Cipta.

Teguh. S. (2004). Kemitraan dan Model-Model Pemberdayaan. Yogyakarta: Graha Ilmu. 